\title{
Factors Associated with the Non Detection of the Sentinel Node in Breast Cancer
}

\author{
Sara Guirao, Ana Benítez Segura, Maria Tereza Bajén, Ynonet Ricart Brulles, Jaume \\ Mora Salvado, Ana Domenech Vilardell, Alba Rodriguez Gassen, Manel Roca Engronyat, \\ Rafael Puchal Añe and Josep Martin-Comin* \\ S. Medicina Nuclear; Hospital Universitario de Bellvitge-IDIBELL; Hospitalet de Llobregat; \\ jmartincomin@csub.scs.es; Espanha
}

\begin{abstract}
The aim of the work was to analyse the potential influence of different factors on the surgical detection of sentinel lymph node in breast cancer. The procedure has been performed in 704 patients. In 43 out of the 704 cases, the SN was not detected, 24 were palpable and 19 had no palpable tumors. Lymphoscitigraphy was done in 2 h p.i. of 37-55 $\mathrm{MBq}$ of 99mTc-nanocolloid. The day before surgery in palpable tumours and $4 \mathrm{~h}$ previous to surgery in nonpalpable tumours, surgical detection was performed using a gammaprobe. The following factors were analysed: patient age, tumour size, breast quadrant tumour localization, scintigraphic visualizatio, $n$ and the palpation of the tumour. Results: Patient age was significantly $(p<0.001)$ higher in the patients in whom SN was not detected. Scintigraphic visualization was significantly $(p<0.05)$ lower in the patients in whom SN was not detected. There were no significant differences concerning the other parameters analysed. Conclusion: patient age and scintigraphic visualization are parameters that directly influence the detection of sentinel node in breast cancer.
\end{abstract}

Key words: Sentinel node, breast cancer

\section{INTRODUCTION}

The radioisotopic detection of the sentinel node $(\mathrm{SN})$ is an established technique in the management of different types of cancer, especially malignant melanoma and breast cancer. In relation to the latter, its application in tumors of less than $3 \mathrm{~cm}$ is widely accepted, and this application allows reduction in the morbidity by diminishing the extension of surgery and, on the other hand, contributes to the staging of the disease (1). In this center, the clinical application of SN methodology in breast cancer began in 2000. In this period more than 1000 patients with mammary tumors have been studied, and the method has also been applied to malignant melanoma, to head and neck tumors and to carcinomas of penis and vulva.

Unfortunately, the surgical location of the $\mathrm{SN}$ is not always possible. In some patients with nonestablished causes, no uptake of radiotracer by lymph nodes was observed, neither in vivo nor es vivo following lymphadenectomy. In this work, some of the factors that could be related to this nondetection are analyzed.

\section{MATERIAL AND METHODS}

This retrospective analysis includes 703 patients operated in this centre for breast carcinoma and in whom a sentinel lymph node study was made. Of

\footnotetext{
*Author for correspondence
} 
these patients, 366 had palpable and 337 nonpalpable tumours. A dose of $37-55 \mathrm{MBq}$ of 99mTc-nanocolloid was peritumorally administered (nanocoll $\AA$ ), by palpation in the palpable tumours and with ultrasonographic/mamographic guidance in the non-palpable tumuors.

Lymphscintigraphy was performed in all cases at 2 h p.i., and the surgical detection occurred at 18-24 $\mathrm{h}$ in the palpable tumours and between 4-5 h postadministration in the non-palpable tumours.

Upon surgery at least one sentinel lymph node was found in each of the 660 patients (94\%) - group I and the SN was not detected in the 43 remaining patients - group II. In all cases,: the age of the patient, the size of the tumour measured in the surgical region, the palpation or not of the tumour as well as its localization in external quadrants or internal quadrants and the visualization of the sentinel node in the scintigraphy were registered. The frequency of visualization of drainage to the internal mammary chain in both groups was also analyzed. The statistical analysis was achieved with the chi-square test, the Fisher test and the model of logistic regression test, multifactorial study, using the programme SPSS.

\section{RESULTS}

In the group I (sentinel node detection, $\mathrm{N}=660$ ), 342 were palpable tumours (52\%) and 318 were non-palpable (48\%). The age of the patients was between 27 and 88 years, with an average age of $57 \pm 12$ years. The mean size of the tumours was $17 \pm 12 \mathrm{~mm}$. Ninety-three percent of the tumours were localised in external and $7 \%$ in the internal quadrants. In the group II (no sentinel node detection, $\mathrm{N}=43$ ), 24 were palpable tumours $(56 \%)$ and 19 were non-palpable (44\%). The age of the patients ranged from 43 to 83 years, with an average age of $66 \pm 10$ years, and the mean tumour size was $20 \pm 10 \mathrm{~mm}$. Ninety-three percent of the tumours were localised in external and $7 \%$ in the internal quadrants.

Surgically, the sentinel node was detected in $98 \%$ of the patients with positive scintigraphy and in only $58 \%$ of those in whom no tracer uptake was seen in the lymphoscintigraphy. The statistical study showed significant differences between both groups in the age of the patients $(\mathrm{p}<0.05)$, as well as in the scintigraphic visualization $(\mathrm{p}<0.001)$. The drainage to internal mammary chain was observed in $9 \%$ of the patients in which the sentinel lymph node was detected and in $7 \%$ of the patients in whom it was not detected.

\section{DISCUSSION}

The study analyzed several factors that may be related to the surgical detection of the sentinel node. The results showed significant differences between both groups (detection and non-detection) with respect to the age of the patients and the lymphoscintigraphic visualization. The age of the patients was significantly greater in the nondetection group, an observation that agrees with the results reported by other authors (3-4). This is not a surprising result, since the changes that evolve in the mammary tissue and the lymphatic system, inherent to age, justify this finding. It is an instructive result, and one must agree with Valdés et al. (4) when they suggest an increase in the activity administered to patients with an age superior to 60 years. In fact, in this center, patients older than 60 years receive an activity $50 \%$ greater than those of inferior age. It is too early to establish comparisons, but the first results seem to indicate improved SN detection.

The lymphoscintigraphy is fundamental in the procedure, although the absence of uptake does not exclude the surgical search for the sentinel node. The visualization of one or more lymph nodes in the lymphoscintigraphy facilitates their surgical detection, furnishes information about extra-axillary localization (namely internal mammary chain drainage) and, altogether, contributes to reduce the time required for surgery, with the consequent benefit for the patient.

Differences related to the size or the location of the tumour have not been observed. This absence of significance could be explained because most of the patients were staged $\mathrm{T} 1-\mathrm{T} 2$, which means that tumour size was quite homogeneous.

Concerning the tumour localization, it has been suggested that tumours located in the internal quadrants would be associated with a greater number of false negatives $(3,5,6)$. However they have not been associated with a smaller rate of detection of the lymph nodes

Differences related to the palpation or not of the tumour have not been observed, as has already been described (7). The application of the 
methodology in the non-palpable tumours is currently a habitual practice.

As this study is a retrospective, clinical study, in patients in whom axillar lymphadenectomy has not been performed, it has not been possible to analyse the frequency of false negative results. The main repercussion of this study at this centre has been to increase the administered activity in aged patients to facilitate the surgical detection of the sentinel node.

\section{RESUMO}

O objetivo deste trabalho foi analisar a possível influencia de diferentes fatores na detecção cirúrgica de linfonodos sentinela no câncer de mama. O procedimento foi realizado em 704 pacientes. Em 43 dos 704, o linfonodo sentinela não foi detectado, 24 eram palpáveis e 19 eram tumores não palpáveis. Foi realizada a linfocintilografia 2 horas após a injeção de 37$55 \mathrm{MBq}$ de $99 \mathrm{mT}$ c-nanocolóide. No dia anterior à cirurgia nos tumores palpáveis e nas 4 horas prévias à cirurgia de tumores não palpáveis foi realizada detecção cirúrgica com a gammaprobe. Foram analisados os seguintes fatores: idade do paciente, tamanho do tumor, quadrante de localização do tumor de seio, visualização cintilográfica e palpação do tumor. Resultados: a idade do paciente foi significativamente maior $(\mathrm{p}<0,001)$ nos pacientes nos quais o nódulo sentinela não foi detectado. Não foram observadas diferenças estatisticamente significativas com relação ao outros parâmetros estudados. A idade do paciente e a visualização cintilográfica são parâmetros que influenciam diretamente na detecção de nódulo sentinela em câncer de mama.

\section{REFERENCES}

Veronesi, U; Paganelli, G.; Viale, G.; Galimberti, V.; Luina, T. O.; Zorrina, S. et al. (1999), Sentinel lymph node biopsy and axillary detection in breast to cancer: results in a large series. J. Natl. Cancer Inst., 91, 368373.
Veronesi, O. R.; Paganelli, G.; Viale, G.; Luini, T. O.; Zurrida, S.; Galimberti, V.; Intra, M.; Veronesi, P.; Robertson, C.; Maisonneuve, P.; Renne, G.; Of Cicco, C.; Bright, F. and Gennari, R. (2003), A randomized comparison of sentinel-node biopsy with routine axillary dissection in breast cancer. N. Engl. J. Med., 349, 546-53.

McMasters, K. M.; Tuttle, T. M.; Carlson, D. J.; Brown, C. M.; Royes, R. D.; Glaser, R. L. et al. (2000), Sentinel lymph node biopsy in breast to cancer: a suitable alternative to routine axillary disection in multi-institutional practice when optimal technical is used. J. Clin. Oncol., 18, 2560-2566.

Valdes-Olmos, R. A.; Jansen, L.; Hoefnagel, C. A.; Nieweg, O. E.; Muller, S. H.; Rutgers, E. J. and Kroon, B. B. (2000), Evaluation of mammary lymphoscintigraphy by a single injection for sentinel node identification. J. Nucl. Med., 41, 1500-6.

Borgstein, P. J.; Pijpers, R.; Comans, E. F.; van Diest, P. J.; Boom, R. P. and Meijer, S. (1998), Sentinel lymph node biopsy in breast cancer.guidelines and pitfalls of lymphoscintigraphy and gamma probe detection. J. Am. Coll. Surg., 186, 275-283

Tafra, L.; Lannin, D. R.; Swanson, M. S.; van Eyck, J. J.; Verbanack, K. M.; Chua, A. N. et al. (2001), Multicentre trial of sentinel node biopsy for breast to cancer using both technetium sulfur colloid and isosulfan blu dye. Ann. Surg., 233, 51-59

Fernandez, A.; Escobedo, A.; Benito, E.; Azpeitia, D.; Guma, A.; Prieto, L.; Moreno, A. and Martin-Comin, J. (2002), Sentinel node localization in patients with non-palpable breast cancer. Nucl. Med. Commun., 23:1165-1169.

Cortes Romera, M. Bajen, M. T.; Fernandez Leon, A.; Benito, E.; Azpeitia, D.; Prieto, L.; Moreno, A.; Ricart, Y.; Escobedo, A. and Martin-Comin, J. (2004), Detección del ganglio centinel en pacientes con cancer de mama. Influencia de la edad de los pacientes y del tamaño tumoral. Rev. Esp. Med. Nucl., 23, 3-8. 